\title{
INTERAÇÕES DISCURSIVAS E PRÁTICAS EPISTÊMICAS EM SALAS DE AULA DE CIÊNCIAS
}

Adjane da Costa Tourinho e Silva*
Universidade Federal de Sergipe (UFS)

RESUMO: Neste artigo apresentamos uma discussão envolvendo a adoção do conceito de práticas epistêmicas em análises de interações discursivas desenvolvidas em aulas de ciências. Consideramos os resultados de duas pesquisas em que investigamos as ações de grupos de estudantes ao longo de atividades investigativas, buscando verificar as relações entre as práticas epistêmicas por eles desenvolvidas e as estratégias articuladas pela professora na condução das atividades. A análise contou com categorias presentes na literatura da área e outras elaboradas ao longo das pesquisas. O conceito de práticas epistêmicas, segundo uma perspectiva sociocultural de educação, ressalta o papel de uma comunidade de prática qualquer na decisão sobre o que pode ser considerado conhecimento relevante e as formas adequadas de construí-lo. Nessa perspectiva, as atividades investigativas desenvolvidas pelos grupos de alunos analisados geraram espaço para uma variedade de práticas epistêmicas, distribuídas nas instâncias sociais de produção, comunicação e avaliação do conhecimento.

Palavras-chave: Movimentos epistêmicos. Práticas epistêmicas. Atividades investigativas.

\section{INTERACCIONES DISCURSIVAS Y PRÁCTICAS EPISTÉMICAS EN AULAS DE CIENCIAS}

RESUMEN: Presentamos en este artículo una discusión acerca de la adopción del concepto de prácticas epistémicas en análisis de interacciones discursivas desarrolladas en clases de ciencias. Se consideraron los resultados de dos investigaciones en las cuales analizamos acciones de grupos de estudiantes a lo largo de actividades investigativas, buscando verificar las relaciones entre prácticas epistémicas desarrolladas por ellos y las estrategias articuladas por la profesora en la realización de las actividades. El análisis incluye categoriás presentes en la literatura del campo de la educación y otras elaboradas a lo largo de las investigaciones. El concepto de prácticas epistémicas, segundo una perspectiva sociocultural de la educación, resalta el papel de una comunidad de cualquier práctica en la decisión de lo que puede ser considerado conocimiento relevante y las formas adecuadas de construirlo. En esa perspectiva, las actividades investigativas desarrolladas por los grupos de alumnos analisados abrieron espacio para una variedad de práticas epistémicas, distribuidas en las instancias sociales de produción, comunicaión y evaluación del conocimiento.

Palabras clave: Movimientos epistémicos. Prácticas epistémicas. Actividades investigativas.

DOI - http://dx.doi.org/10.1590/1983-2117201517s05 


\section{DISCURSIVE INTERACTIONS AND EPISTEMIC PRACTICES IN SCIENCE CLASSROOMS}

ABSTRACT: This paper presents a discussion about the adoption of the epistemic practices concept in analysis of discursive interactions developed in science classrooms. We consider the results of two studies in which we analyze the actions of students groups throughout investigative activities, in order to verify the relation between epistemic practices developed by them and strategies articulated by the teacher conducting activities. The analysis counted with categories present in education's literature, as well as other categories developed while the research was conducted. The concept of epistemic practices, according to a sociocultural perspective of education, emphasizes the role of a community of any practice in deciding what can be considered relevant knowledge and appropriate ways to build it. Under this perscpective, the investigative activities developed by the analyzed student groups created space to a epistemic practice variety, distributed in production, communication and knowledge evaluation's social instances.

Keywords: Epistemic movements. Epistemic practices. Investigative activities. 


\section{INTRODUĈ̣̃O}

\section{A perspectiva de análise}

A assunção de uma perspectiva sociocultural na Educação em Ciências dirige o foco das atenções, tanto no ensino quanto na pesquisa, para as interações que se desenvolvem no plano social da sala de aula. Discutindo sobre o delineamento dessa perspectiva analítica, Lemke (2001, p. 1, tradução nossa) argumenta que a sua incorporação na Educação em Ciências significa, fundamentalmente, conceber "[...] a Ciência, a Educação em Ciências e a pesquisa em Educação em Ciências como atividades sociais humanas, conduzidas dentro de esquemas culturais e institucionais". Nesse sentido, a interação social, de acordo com a tradição vygotskiana, assume um relevante papel nas pesquisas inseridas nessa linha, uma vez que se constitui em um aspecto central na apropriação dos sistemas de recursos sociais semióticos e das formas socialmente significantes de usá-los, os quais constituem a cultura de uma comunidade qualquer.

Perceber a sala de aula como um espaço sociocultural sinaliza para a importância de compreender como os diversos processos aí desenvolvidos são construídos discursivamente, o que faz as atenções voltarem para as interações e os diálogos que se estabelecem entre os sujeitos deste ambiente, considerando-se os diferentes papéis que eles assumem.

A constituição de perspectivas socioculturais na Educação em Ciências traz, necessariamente, para este campo, uma nova percepção de ciência. Estudos desenvolvidos nas áreas da História e da Sociologia da Ciência, da Etnosciência na Antropologia Cultural e estudos sobre a Ciência Contemporânea, desde a década de 1960, contribuem para a percepção da ciência como prática situada socialmente, sustentada em critérios estabelecidos discursivamente, os quais dão legitimidade aos conhecimentos produzidos. Tal percepção tem, de diferentes formas, fornecido bases para orientações curriculares, propostas pedagógicas, bem como inspirado pesquisas que, mais recentemente, têm se voltado para análise das práticas e dos compromissos epistemológicos dos estudantes no desenvolvimento de suas investigações escolares.

Kelly e Duschl (2002) discutem que o movimento em direção às investigações empíricas sobre as práticas dos cientistas potencialmente informa novas práticas na Educação em Ciências. Os autores apresentam o conceito de práticas epistêmicas, as quais são compreendidas como formas específicas com que membros de uma comunidade inferem, justificam, avaliam e legitimam asserções de conhecimento.

Kelly (2005) enfatiza a atenção às formas pelas quais o conhecimento é construído e justificado dentro de uma comunidade particular. Argumenta que uma comunidade justifica o seu conhecimento por meio de práticas sociais, as quais são entendidas como um conjunto de ações padronizadas, baseadas em intenções e expectativas comuns de indivíduos que compartilham valores e ferramentas culturais. Quando tais ações relacionam-se ao conhecimento, são 
chamadas de práticas epistêmicas. Kelly e Duschl (2002) ressaltam, portanto, que um importante aspecto para participação na ciência é a aprendizagem de práticas epistêmicas, as quais se associam às instâncias sociais de produção, comunicação e avaliação do conhecimento. Nessa perspectiva, chamam atenção para o importante papel de uma comunidade de prática qualquer na decisão do que conta como conhecimento relevante e das formas adequadas de construí-lo.

O conceito de práticas epistêmicas associa-se, assim, a uma mudança de sujeito epistêmico, que passa de um conhecedor individual para uma comunidade de prática. Nessa perspectiva, no contexto escolar, o foco analítico afasta-se de uma consciência individual e volta-se para o processo social de investigação, em que são valorizadas as interações discursivas entre alunos e professor e de alunos entre si quando estes se envolvem na construção e na legitimação de conhecimentos.

A premissa de que o ensino de ciências deve proporcionar ao aluno uma adequada percepção das dimensões discursiva e argumentativa da ciência, bem como da natureza dos saberes científicos, sustenta o planejamento de ambientes de aprendizagem investigativos e a análise do processo de construção e justificação dos saberes pelos alunos ao longo de suas investigações. Quanto a isso, o interesse por aspectos epistêmicos na Educação em Ciências tem gerado diferentes propostas de ferramentas para análise do movimento epistêmico dos estudantes e do suporte dado pelos professores na configuração desses movimentos, bem como agendas de pesquisa nessa direção (SANDOVAL, 2001; KELLY; TAKAO, 2002; TAKAO; KELLY, 2003; KELLY; DUSCHL, 2002; SANDOVAL; MORRISON, 2003; SANDOVAL; RESIER, 2004; SANDOVAL, 2005; WICKMAN, 2004; KELLY, 2005, LIDAR; LUNDQVIST; OSTMAN, 2005; JIMÈNEZ-ALEIXANDRE; REIGOSA, 2006).

Dessa forma, estabelece-se uma linha de pesquisa que busca verificar como aspectos fundamentais do discurso científico são incorporados e expressos pelos alunos quando estes desenvolvem atividades investigativas, geralmente em torno de problemas autênticos. As atenções recaem no processo de construção e justificação dos saberes in situ, em que os alunos produzem e validam, por meio de um movimento argumentativo, os saberes em suas investigações escolares.

Ao mesmo tempo que a literatura sobre o tema nos chama atenção para a importância de lançar novos olhares para o discurso dos alunos ao longo das atividades investigativas, também instiga o nosso interesse pelos discursos dos professores, em suas tentativas de favorecer o desenvolvimento das práticas epistêmicas. Dessa forma, consideramos relevante enfatizar as relações entre esses sujeitos da sala de aula - professor e alunos - considerando-se os aspectos epistêmicos que permeiam as atividades investigativas.

Interessa-nos, neste artigo, discutir sobre os resultados de pesquisas que vimos desenvolvendo, considerando o conceito de práticas epistêmicas, bem como os aspectos metodológicos envolvidos. Tendo em vista uma revisão de literatura sobre o tema, ressaltamos algumas categorias analíticas que temos usado e as opções metodológicas referentes à construção e à análise dos dados. 


\section{As pesquisas}

O problema central das pesquisas discutidas neste artigo é estabelecer relações entre as práticas epistêmicas desenvolvidas por alunos em atividades investigativas estruturadas de ciências e as ações do professor, de modo a perceber aspectos dessas ações que favorecem o desenvolvimento de tais práticas, considerando-se sequências de ensino elaboradas nessa direção. Enquanto as ações dos alunos desenvolvidas ao longo de atividades investigativas são chamadas de práticas epistêmicas, como consagrado na literatura da área, chamamos as ações dos professores, ao conduzirem as atividades investigativas, de movimentos epistêmicos.

Ao focalizarmos as ações dos professores, considerando seus aspectos interativos, levamos em conta categorias inseridas na dimensão da interatividade da ferramenta analítica proposta por Mortimer et al. (2007). Consideramos também algumas categorias inspiradas naquelas propostas por Lidar, Lundquivist e Östman (2005). Tais categorias (epistemological moves) voltam-se para a análise do discurso/ ações de professores, relacionando-os com a epistemologia prática dos estudantes, ou seja, as formas como estes consideram, em suas atividades, o que conta como conhecimento relevante e os meios relevantes de obtê-lo. Os epistemological moves são entendidos como as formas pelas quais o professor dá as orientações nesse processo. Nesse sentido, considera-se que o professor, em interação com os estudantes, apresenta várias ações práticas ou conversacionais que podem ser pensadas, de acordo com as suas funções, como epistemológicas.

Os movimentos epistêmicos considerados neste trabalho referem-se, portanto, às intervenções do professor nas atividades investigativas de um grupo de alunos, que podem ser percebidas como questionamentos, sugestões e orientações significativas para o seu avanço intelectual, favorecendo a adoção de determinadas práticas epistêmicas. Estas últimas, por sua vez, foram delimitadas baseando-se naquelas apresentadas por Jimènez-Aleixandre et al. (2008), tendo-se em vista as instâncias sociais de produção, comunicação e avaliação do conhecimento propostas por Kelly (2005).

\section{ASPECTOS TEÓRICO-METODOLÓGICOS}

Antes de discutirmos os aspectos de coleta, tratamento e análise dos dados, vamos apresentar as principais categorias que consideramos em nossa análise.

\section{Ações do professor}

\section{As categorias analíticas}

Os movimentos epistêmicos considerados neste trabalho foram:

1. Elaboração: corresponde às ações do professor que possibilitam aos alunos, em geral por meio de questionamentos, construir um olhar inicial sobre o fenômeno. São os questionamentos expressos nos roteiros de atividade ou mesmo proferidos oralmente pelo professor, os quais geram 
espaço para que os alunos reflitam segundo determinada perspectiva e exponham seus pontos de vista sobre os objetos e os eventos investigados.

2. Reelaboração: corresponde às ações do professor que instigam os alunos, por questionamentos ou breves afirmações, a observarem aspectos desconsiderados ou a trazerem à tona novas ideias, favorecendo uma modificação ou uma problematização do pensamento inicial apresentado.

3. Instrução: quando o professor apresenta explicitamente novas informações para os alunos.

4. Confirmação: quando o professor concorda com as ideias apresentadas pelos alunos e/ou permite que eles executem determinados procedimentos planejados.

5. Correção: quando o professor corrige explicitamente as afirmações e os procedimentos dos alunos.

6. Síntese: quando o professor explicita as principais ideias alcançadas pelos alunos.

7. Compreensão: quando o professor busca apenas compreender por meio de questionamentos determinados procedimentos e ideias apresentadas pelos alunos.

Utilizamos também outro conjunto de categorias para classificar o discurso do professor: a abordagem comunicativa (MORTIMER; SCOT'T, 2003). O conceito de abordagem comunicativa fornece a percepção sobre a abertura do discurso do professor para os pontos de vista dos alunos, em interação ou não com eles. De acordo com Mortimer e Scott (2003), tal discurso pode ser caracterizado em duas dimensões. A primeira pode ser percebida como um contínuo entre dois polos extremos: no primeiro, o professor atenta-se para o que os estudantes têm a dizer considerando seus próprios pontos de vista; no segundo extremo, o professor observa o que os estudantes têm a dizer apenas do ponto de vista da ciência escolar. A primeira dessas posições, que permite uma interanimação de diferentes ideias, é chamada de abordagem comunicativa dialógica, e a segunda, de abordagem comunicativa de autoridade.

Um importante aspecto a ser considerado é que uma sequência de fala pode ser de natureza dialógica ou de autoridade, independentemente de ser enunciada individualmente ou por várias pessoas. O que faz o discurso ser funcionalmente dialógico é o fato de diferentes ideias serem consideradas, e não o fato de ser produzido por um grupo de pessoas ou por um único indivíduo (MORTIMER; SCOTT, 2003). Isso leva os autores a apresentarem a segunda dimensão da abordagem comunicativa; esta considera que a abordagem pode ser interativa, quando envolve a participação de mais de uma pessoa, ou não interativa, quando envolve a participação de apenas uma. Combinando essas duas dimensões, tem-se um conjunto de quatro categorias que são usadas para codificar a abordagem comunicativa: 1 - Interativa e dialógica (I/D); 2 - Interativa e de autoridade (I/A); 3 - Não interativa e dialógica $(N I / D) ; 4$ - Não interativa e de autoridade $(N I / A)$. 
Para lidar com as ações dos alunos, suas práticas epistêmicas, consideramos algumas das categorias apresentadas por Jimènez-Aleixandre et al. (2008), conforme quadro que segue. Na primeira coluna, encontram-se as instâncias sociais de produção, comunicação e avaliação do conhecimento propostas por Kelly (2005); na segunda coluna, encontram-se práticas epistêmicas gerais relacionadas às instâncias da primeira coluna; e, na terceira coluna, encontram-se práticas mais específicas.

Quadro 1: Práticas epistêmicas e sociais em relação com o conhecimento

\begin{tabular}{|c|c|c|}
\hline $\begin{array}{l}\text { Instâncias } \\
\text { sociais }\end{array}$ & Práticas epistêmicas gerais & Práticas epistêmicas (específicas) \\
\hline Produção & Articular os próprios saberes; & $\begin{array}{l}\text { Monitorando o progresso; } \\
\text { Executando estratégias orientadas por } \\
\text { planos ou objetivos; } \\
\text { Utilizando conceitos para planejar e realizar } \\
\text { ações (por exemplo, no laboratório); } \\
\text { Articulando conhecimento técnico na } \\
\text { execução de ações (por exemplo, no } \\
\text { laboratório); } \\
\text { Construindo significados; } \\
\text { Considerando diferentes fontes de dados; } \\
\text { Construindo dados. }\end{array}$ \\
\hline Comunicação & $\begin{array}{l}\text { Interpretar e construir as } \\
\text { representações; } \\
\text { Produzir relações; } \\
\text { Persuadir os outros membros } \\
\text { da comunidade. }\end{array}$ & $\begin{array}{l}\text { Relacionando/traduzindo diferentes } \\
\text { linguagens: observacional, } \\
\text { representacional e teórica; } \\
\text { Transformando dados; } \\
\text { Seguindo o processo: questões, plano, } \\
\text { evidências e conclusões; } \\
\text { Apresentando suas próprias ideias e } \\
\text { enfatizando os aspectos cruciais; } \\
\text { Negociando explicações. }\end{array}$ \\
\hline Avaliação & $\begin{array}{l}\text { Contrastar as conclusões } \\
\text { (próprias ou alheias) com } \\
\text { as evidências (avaliar a } \\
\text { plausibilidade) -argumentação. }\end{array}$ & $\begin{array}{l}\text { Distinguindo conclusões de evidências; } \\
\text { Utilizando dados para avaliação de teorias; } \\
\text { Utilizando conceitos para interpretar os dados; } \\
\text { Contemplando os mesmos dados de } \\
\text { diferentes pontos de vista; } \\
\text { Recorrendo a consistência com outros } \\
\text { conhecimentos; } \\
\text { Justificando as próprias conclusões; } \\
\text { Criticando declarações de outros; } \\
\text { Usando conceitos para configurar } \\
\text { anomalias. }\end{array}$ \\
\hline
\end{tabular}

Fonte: JIMÈNEZ-ALEIXANDRE et al., 2008, traduzido e adaptado. 
Os autores salientam que a demarcação entre as atividades sociais de produção, comunicação e avaliação do conhecimento nem sempre é clara. Observam ainda que a sistematização que apresentam das práticas epistêmicas não é exaustiva. Nesse sentido, embora a sistematização apresentada pelos autores seja referência para nossa análise, não tivemos a intenção de necessariamente identificar em todas as ações dos alunos pesquisados as práticas relacionadas. Ao contrário, caracterizamos também novas práticas, as quais se encontram, entre outros aspectos, intimamente relacionadas à estrutura da atividade desenvolvida.

\section{A CONSTRUÇÃO DOS DADOS}

Os dados da análise apresentada neste artigo referem-se a duas situações de ensino distintas: a primeira delas (Situação 1) envolveu duas das quatro aulas em que os alunos de uma turma de $9^{\circ}$ ano do Colégio de Aplicação da UFS desenvolveram uma atividade investigativa intitulada "Densidade e flutuação dos objetos". Foram consideradas as ações da professora ao longo das aulas e as de um grupo de cinco alunos tomado para análise. A pesquisa foi desenvolvida durante as aulas regulares da turma; todavia, a professora considerada não era a professora regular, e, sim, uma integrante do grupo de pesquisa ${ }^{2}$ que se revezou na condução da atividade com outros integrantes, alunos de iniciação científica envolvidos no projeto. A segunda situação (Situação 2) envolveu um encontro com duração de pouco mais de duas horas, o qual se constituiu em parte de uma oficina realizada também no referido colégio durante um evento de popularização da ciência. A oficina envolveu o desenvolvimento de uma atividade investigativa em torno do tema "reações químicas". A turma era formada por 23 alunos de oitavos e nonos anos do Ensino Fundamental, e o grupo tomado para análise também era composto por cinco alunos. A professora que conduziu a atividade foi a mesma que atuou na Situação 1.

Em ambas as situações, os dados, registrados em vídeo, foram submetidos a análise por meio do software Videograph ${ }^{\circledR}$, para obtenção de percentuais de tempo das categorias empregadas. As aulas foram também mapeadas, sendo segmentadas em episódios e sequências discursivas. Ao tempo em que nos preocupamos com uma análise qualitativa, em que descrevemos e analisamos as ações da professora e dos alunos em interação, lançamos mão de dados quantitativos, os quais nos permitiram verificar o peso de cada categoria ao longo das atividades investigativas.

Os mapas de episódios nos possibilitaram perceber o ritmo com que as categorias apareciam e davam lugar umas às outras no fluxo das interações; portanto, favoreceram uma percepção mais nítida das relações entre as ações da professora e o trabalho do grupo de alunos investigado. Por meio do mapa, foi possível verificar como, ao longo da atividade, o discurso e as intenções da professora se alternaram de um episódio a outro da aula e, ainda, como as ações da professora foram sucedidas por determinadas práticas epistêmicas. Também foi 
possível verificar a variação nas ações dos alunos. Nessa perspectiva, os episódios ou suas subdivisões (sequências discursivas) mais representativos do movimento discursivo que caracterizou cada situação investigada foram transcritos. As transcrições que apresentamos na seção a seguir foram selecionadas buscando evidenciar tal movimento, focalizando tanto a atuação dos alunos quanto a da professora na condução da atividade.

\section{RESULTADOS E DISCUSSÃO}

Em ambas as situações, as atividades investigativas foram desenvolvidas tendo-se em vista um roteiro previamente organizado. Os alunos seguiram as instruções desse roteiro quanto aos procedimentos de coleta e de análise dos dados, os quais reservavam, por meio de questões propostas, bastante espaço para a discussão entre eles nos pequenos grupos e com toda a turma.

Situação 1: A atividade envolveu quatro aulas geminadas duas a duas. Nas duas primeiras, foi construído o conceito de densidade. Nas duas seguintes, focalizadas na análise que aqui apresentamos, o objetivo foi promover a compreensão da relação entre a densidade e a flutuação de objetos em determinado meio. ${ }^{3}$

Com base nas tarefas e nas questões propostas, pretendeu-se que os alunos alcançassem a generalização de que os objetos feitos de material de densidade maior que a de um determinado meio afundam em tal meio, enquanto aqueles menos densos flutuam, independentemente da sua massa ou do seu volume separadamente. Além disso, a influência da forma do objeto teria que ser considerada, de modo a se perceber que, apesar de objetos feitos de materiais mais densos que a água, como, por exemplo, a tampinha de refrigerante e o papel-alumínio, flutuarem sob certas condições nesse líquido, isso não se constituiria em uma exceção à regra geral já alcançada.

A professora iniciou a aula com um episódio de gestão e manejo da classe, em que solicitou atenção e comportamento adequado dos alunos. Em seguida, ela retomou as principais ideias construídas na aula anterior. Nesse momento, ela adotou um discurso não interativo/de autoridade com a intenção de manter a narrativa, ou seja, de rever com os alunos o fluxo das ideias construídas na sequência temática.

Em determinado momento, ela passou a orientar os alunos para o desenvolvimento da atividade (discurso de gestão e manejo de classe). Os alunos foram informados de que teriam que elaborar hipóteses para a flutuação de alguns objetos em água. A professora foi informando aos alunos os objetos que seriam utilizados, até investir mais nitidamente na questão principal que orientaria a atividade, ou seja, ela enfatizou que eles deveriam refletir sobre a flutuação ou não de cada objeto. Nesse sentido, passando a focalizar o conteúdo científico, ela adotou uma abordagem interativa/dialógica, com a intenção de criar um problema para engajar os alunos no desenvolvimento inicial da estória científica. O movimento epistêmico que aí prevaleceu foi o de elaboração, pois, conforme comentamos, 
ele corresponde às ações da professora no sentido de possibilitar uma percepção inicial sobre o fenômeno considerado.

$\mathrm{Na}$ segunda fase da atividade, em que os alunos trabalhavam em pequenos grupos, a professora visitou cada um destes, dando suporte à discussão que desenvolviam. Foram feitas cinco intervenções no grupo analisado, no momento em que os alunos elaboravam hipóteses, antes de partirem para os testes de flutuação. $\mathrm{Na}$ quarta intervenção, da qual faz parte o fragmento que se encontra no Quadro 2 , a professora observou as ideias que os alunos haviam colocado no roteiro da atividade e percebeu que as justificativas para a flutuação ou não dos objetos na água não estavam expostas. A partir disso, ela investiu na explicitação da questão inicial, enfatizando a importância de eles apresentarem tais justificativas. Nesse momento, a sua intenção ainda foi a de criar um problema, uma vez que a questão proposta não havia sido inteiramente assumida pelos alunos. A abordagem comunicativa foi a interativa/dialógica, tendo-se em vista que foi gerado espaço para que os alunos expusessem seu ponto de vista, e o movimento epistêmico inclinou-se ao de reelaboração, pois os alunos foram instigados a refletir mais criteriosamente sobre as suas concepções iniciais e, consequentemente, a modificá-las.

Quadro 2: Intervenção da professora no grupo-pesquisa com o movimento de reelaboração

\begin{tabular}{|l|l|}
\hline \multicolumn{1}{|c|}{ Transcrições } & \multicolumn{1}{|c|}{ Comentários contextuais } \\
\hline Professora: A justificativa... Vocês não colocaram não? & $\begin{array}{l}\text { A professora analisa o roteiro de } \\
\text { atividade e percebe que todas as } \\
\text { previsões foram colocadas sem } \\
\text { justificativa. }\end{array}$ \\
\hline Aluno B: A gente ia colocar // & \\
\hline $\begin{array}{l}\text { Professora: Vocês têm que colocar (lpausadamente)). } \\
\text { Afunda, afunda, não afunda, não afunda ((lê em voz baixa } \\
\text { as respostas dos alunos)]. Vocês têm que deixar bem } \\
\text { claro os critérios, ou seja: por que é que afunda? Por que } \\
\text { é que não afunda? Viu? Coloquem aqui llapontando para } \\
\text { o papel)). É importante! Agora, é importante também que } \\
\text { vocês discutam [...]. }\end{array}$ & \\
\hline
\end{tabular}

Fonte: SILVA et al., 2012.

Até então, os alunos estavam, algumas vezes, apresentando as suas hipóteses de forma sumária, sem justificativa e, outras vezes, recorreram a diferentes critérios de forma assistemática; ou seja, em alguns casos, consideraram a densidade para explicar a flutuação, em outros, a massa, e em vários momentos consideraram experiências do dia a dia, as quais serviam como uma "evidência" de que certo objeto flutuaria ou não na água. Apesar de bastante rica no sentido de trazer à tona 
diferentes aspectos que poderiam estar em jogo na flutuação dos objetos e, portanto, para a reflexão sobre as garantias das asserções elaboradas, a discussão não estava avançando no sentido de os alunos considerarem concepções trabalhadas em aulas anteriores ou mesmo do dia a dia, de forma sistemática. Isso, possivelmente, possibilitaria que percebessem claramente como conflituosas, por exemplo, as hipóteses de um bloco de alumínio afundar em água e de o papel-alumínio, não, apesar de ambos serem do mesmo material e, portanto, apresentarem a mesma densidade. Tal conceito já havia aparecido nas discussões do grupo.

A quarta intervenção da professora, investindo no movimento de reelaboração, pareceu-nos fundamental para o avanço da discussão. Tal investida fez com que alguns alunos refletissem mais sobre suas concepções iniciais e, em alguns casos, modificassem-nas. No Quadro 3, apresentamos excertos das discussões do grupo em episódios anteriores à quarta intervenção da professora. As transcrições nos possibilitaram verificar que as práticas epistêmicas eram, principalmente: "configurando hipóteses", quando os alunos colocavam de forma sumária as suas previsões; e "avaliando a plausibilidade de suas previsões/hipóteses", em que eles buscavam amparar as suas asserções considerando "evidências" do dia a dia, justificando-as. A primeira prática se inseriu na instância social de produção do conhecimento, e a segunda, na instância de avaliação.

Como proposto por Jimènez-Aleixandre et al. (2008), a prática epistêmica (geral) de contrastar ideias próprias com a de outros baseando-se em evidências envolve, entre outras ações, as práticas específicas de justificar as conclusões pessoais e criticar as declarações do outro. Os integrantes do grupo analisado fizeram isso durante todo o tempo em que elaboravam as suas hipóteses, desafiando as dos colegas.

Outro aspecto importante a considerar é o de que, na prática de contrastar suas ideias com a de outros por meio de evidências, os alunos avaliam a plausibilidade das hipóteses próprias e das teses dos colegas, e não a plausibilidade de um conhecimento produzido em decorrência do desenvolvimento da coleta de dados na atividade investigativa. Se fosse essa a situação, a categoria de "contrastar as conclusões (próprias ou alheias) com as evidências (avaliar a plausibilidade)" provavelmente só apareceria em uma fase final da atividade, quando os alunos fossem avaliar se as concepções que formularam estariam de acordo com as evidências experimentais. 
Quadro 3: Práticas epistêmicas de produção e avaliação do conhecimento

\begin{tabular}{|c|c|c|}
\hline Episódio & Transcrição & Prática epistêmica \\
\hline \multirow{2}{*}{8} & $\begin{array}{l}\text { Aluno C: Olhe o isopor não afunda não. O pequeno } \\
\text { flutua. Não, o grande e o pequeno afundam também } \\
\text { ((referindo-se ao bloco de madeira citado pelo aluno A)] } \\
\text { Aluno B: Você não viu não, o bloco de isopor? } \\
\text { [...] } \\
\text { Aluno A: Agulha afunda. Esses dois não afunda. Ou } \\
\text { afunda os dois ou não afunda. (lreferindo-se aos blocos } \\
\text { de madeira grande e pequenol) } \\
\text { Aluno B: Eu sei que afunda. Não é não? }\end{array}$ & $\begin{array}{l}\text { - Apresentando as } \\
\text { suas previsões: } \\
\text { Configurando } \\
\text { hipóteses }\end{array}$ \\
\hline & $\begin{array}{l}\text { [...] } \\
\text { Aluno B: Se o bloco de madeira afundasse não } \\
\text { existiriam barcos de madeira. } \\
\text { Aluno D: É verdade esse negócio. } \\
\text { Aluno C: Você sabia que não é toda madeira que faz } \\
\text { barco? } \\
\text { Aluno A: Sim, porque aquele... } \\
\text { Aluno C: Sabia que se você pegar qualquer madeira } \\
\text { dessa e colocar dentro da água ela não flutua? }\end{array}$ & $\begin{array}{l}\text { - Avaliando a } \\
\text { plausibilidade de suas } \\
\text { previsões/hipóteses. } \\
\text { - Contrastando as } \\
\text { previsões/hipóteses } \\
\text { próprias ou alheias } \\
\text { com “evidências” do } \\
\text { dia a dia. }\end{array}$ \\
\hline 13 & $\begin{array}{l}\text { Aluno D: Tampinha de refrigerante vai afundar? } \\
\text { Conversas paralelas. } \\
\text { Aluno C: Você nunca viu aquelas tampinhas embaixo da } \\
\text { água, da areia da praia não, dentro do mar? } \\
\text { Aluno B: Ah! É verdade. } \\
\text { Aluno D: Dentro do rio. } \\
\text { Aluno B: Eu já vi dentro do canal do Eduardo só que } \\
\text { era tampa de cerveja. ((Refere-se ao bairro Eduardo } \\
\text { Gomes)) } \\
\text { ((Silêncio.)) } \\
\text { Aluno B: Tá, vocês nunca acreditam no que eu falo. }\end{array}$ & $\begin{array}{l}\text { - Avaliando a } \\
\text { plausibilidade de suas } \\
\text { previsões/hipóteses; } \\
\text { - Contrastando as } \\
\text { previsões/hipóteses } \\
\text { próprias ou alheias } \\
\text { com "evidências" do } \\
\text { dia a dia. }\end{array}$ \\
\hline
\end{tabular}

Fonte: SILVA et al., 2012.

Entendemos que a variação no aparecimento de categorias referentes a diferentes instâncias sociais irá ocorrer em função da estrutura da atividade proposta pelo professor. No caso aqui analisado, os alunos foram solicitados a expor e eleger as hipóteses mais plausíveis para a flutuação, com um tempo razoável para discussão. Isso resultou na emergência da instância de avaliação do conhecimento no início da atividade proposta.

Após a quarta intervenção da professora no grupo, os alunos passaram a apresentar as hipóteses considerando, de forma mais sistemática, o conceito de densidade. As hipóteses foram se tornando mais bem-elaboradas, pois as asserções passaram a ser associadas a determinados conceitos que assumiam uma for- 
ma de garantia para as mesmas. Desse modo, os casos mais "controversos" foram adquirindo mais evidência. Os alunos passaram a se deter mais na discussão sobre o papel-alumínio e concluíram que o clipe deveria afundar na água porque seria feito do "mesmo" material que a agulha. Aparecia, nesse momento, de forma mais consistente, a categoria "considerando conceitos para elaborar hipóteses", a qual se insere na instância de produção do conhecimento. Também a prática "concluindo/checando as conclusões" foi realizada quando os alunos recapitularam as ideias já trabalhadas. Tal prática também se insere na instância de produção do conhecimento, como proposto por Araújo (2008). Vejamos os excertos no Quadro 4.

Quadro 4: Práticas epistêmicas de produção e avaliação do conhecimento

\begin{tabular}{|c|c|c|}
\hline Episódio & Transcrição & Prática epistêmica \\
\hline 23 & $\begin{array}{l}\text { Aluno D: Bloco de madeira pequeno. Afunda } \\
\text { ou não afunda? } \\
\text { Aluno B: Não afunda. } \\
\text { Aluno A: A gente já foi unânime. } \\
\text { Aluno E: Não afunda porque a densidade é } \\
\text { menor. }\end{array}$ & \multirow[t]{2}{*}{$\begin{array}{l}\text { - Considerando conceitos para } \\
\text { elaborar hipóteses. }\end{array}$} \\
\hline 25 & $\begin{array}{l}\text { [...] } \\
\text { Aluno D: E o bloco de madeira grande? } \\
\text { Aluno C: É a mesma coisa. Não afunda } \\
\text { porque a densidade é menor que a da água. }\end{array}$ & \\
\hline 27 & $\begin{array}{l}\text { Aluno A: Assim, eu acho que o mais } \\
\text { importante é a massa, véio. } \\
\text { Aluno C: É a densidade, eu acho. } \\
\text { Aluno E: É a densidade. } \\
\text { Aluno B: É sim. } \\
\text { Aluno C: Não é a massa nããão. Se fosse } \\
\text { assim, um navio com não sei quantas } \\
\text { milhões de toneladas afundava, véio. }\end{array}$ & $\begin{array}{l}\text { - Considerando conceitos para } \\
\text { elaborar hipóteses; } \\
\text { - Contrastando as ideias/ } \\
\text { hipóteses próprias ou alheias } \\
\text { com "evidências" do dia a dia. }\end{array}$ \\
\hline 39 & $\begin{array}{l}\text { Aluno B: Ei! Ói as respostas que a gente } \\
\text { botou: não afunda porque tem a densidade } \\
\text { menor que a da água; não afunda porque } \\
\text { tem a densidade menor que a da água; não } \\
\text { afunda porque acumula muito ar. Ai, J.P.! } \\
\text { Não afunda porque o ferro tem a densidade } \\
\text { maior que a da água! } \\
\text { ((Conversas paralelas para consertar } \\
\text { prontamente a última afirmação do aluno)) }\end{array}$ & $\begin{array}{l}\text { - Concluindo/checando as } \\
\text { hipóteses. }\end{array}$ \\
\hline
\end{tabular}


Considerando as discussões dos alunos nos momentos em que elaboravam hipóteses para a flutuação dos objetos na água, pudemos verificar o movimento evolutivo nesse processo de elaboração, conforme sumarizado no Quadro 5.

Quadro 5: Movimento discursivo de elaboração de hipóteses: produção do conhecimento

\begin{tabular}{|l|l|}
\hline \multicolumn{1}{|c|}{ Prática epistêmica } & \multicolumn{1}{c|}{ Descrição } \\
\hline $1^{\text {a }}$ - Configurando hipóteses. & $\begin{array}{l}\text { Os alunos expõem de forma sumária as suas } \\
\text { previsões. }\end{array}$ \\
\hline $\begin{array}{l}2^{\mathrm{a}}-\text { Avaliando a plausibilidade das } \\
\text { hipóteses. }\end{array}$ & $\begin{array}{l}\text { Os alunos contrastam as ideias/hipóteses próprias ou } \\
\text { alheias com as evidências do dia a dia. }\end{array}$ \\
\hline $\begin{array}{l}3^{a}-\text { Considerando conceitos para } \\
\text { elaborar hipóteses. }\end{array}$ & $\begin{array}{l}\text { Os alunos passam a considerar conceitos (densidade, } \\
\text { massa e volume) para sustentar as suas previsões, } \\
\text { articulando-os em vários momentos a evidências do } \\
\text { dia a dia. }\end{array}$ \\
\hline
\end{tabular}

Fonte: Elaboração pelos autores deste artigo.

Após a realização dos testes de flutuação dos objetos pela professora, os alunos foram solicitados a elaborar uma regra geral, ou seja, uma generalização que pudesse compor uma justificativa para os comportamentos dos blocos de madeira (grande e pequeno), do cilindro de alumínio, da agulha e do clipe em água. A partir daí, apareceram as práticas "ordenando dados" - a qual se insere na instância de produção do conhecimento-, "negociando explicações para os resultados obtidos" e "alcançando generalizações". Essas duas últimas, por sua vez, inserem-se na instância de comunicação do conhecimento, uma vez que correspondem a uma interpretação dos dados (e à construção de representações) e à sua adequação a uma forma de comunicá-los. Os excertos do Quadro 6, dos episódios 47 e 51, tornam clara essa descrição. 
Quadro 6: Práticas epistêmicas de produção e comunicação do conhecimento

\begin{tabular}{|c|c|c|}
\hline Episódio & Transcrição & Prática epistêmica \\
\hline 47.1 & $\begin{array}{l}\text { Aluno C: É assim, ói: a tampinha, ela em } \\
\text { repouso ela flutua. Agora ói, Pera aí. A } \\
\text { tampinha em repouso, ela flutua, agora a } \\
\text { tampinha se passar a atuar sobre ela uma } \\
\text { força resultante, que resulte / uma força } \\
\text { resultante, ela afunda. }\end{array}$ & Negociando explicações. \\
\hline 47.2 & $\begin{array}{l}\text { Aluno D: Compare as justificativas } \\
\text { apresentadas na tabela com os resultados } \\
\text { obtidos pelos testes. Quais não foram } \\
\text { confirmadas? ((O aluno lê a questão proposta } \\
\text { no roteiro de atividade)) } \\
\text { Aluno C: Nenhum. } \\
\text { Aluno B: Não teve. }\end{array}$ & Ordenando dados. \\
\hline 51 & $\begin{array}{l}\text { Aluno C: Vocês seriam capazes de formular } \\
\text { uma regra geral que fosse capaz de prever } \\
\text { quais objetos flutuariam e quais afundariam } \\
\text { na água? ((O aluno lê a questão proposta no } \\
\text { roteiro de atividade)) } \\
\text { [.... } \\
\text { Aluno A: Só podemos nos basear em/ } \\
\text { Aluno D: Acho que conseguiremos. } \\
\text { Aluno E: Também. } \\
\text { Aluno D: Só termos a densidade de cada um: } \\
\text { alumínio, ferro, a da água e da madeira. } \\
\text { Aluno B: Eu falei isso e ninguém me escutou. }\end{array}$ & Alcançando generalizações. \\
\hline
\end{tabular}

Fonte: Elaboração pelos autores deste artigo.

É interessante verificar como as práticas de produção e de comunicação do conhecimento se intercalaram. Isso se deu em função da estrutura da atividade proposta, na qual, ao tempo em que os alunos produziam conhecimento (elaborando e ordenando dados), buscavam responder às questões do roteiro, as quais solicitavam interpretações e generalizações, práticas estas inseridas na instância de comunicação.

A discussão apresentada até o momento enfatiza o desenvolvimento das práticas epistêmicas dos estudantes relacionadas ao investimento da professora nos movimentos epistêmicos de elaboração e reelaboração, estando estes aliados a uma abordagem dialógica e à intenção de criar um problema. Seguindo-se esse ritmo discursivo, após ter percebido que os alunos alcançaram uma generalização frente aos testes realizados, a professora estabeleceu uma discussão com toda a turma, com a intenção de explorar os pontos de vista dos alunos com relação aos comportamentos da tampinha de refrigerante e do papel-alumínio, que aparentemente contrariavam a generalização alcançada. 
Com tal intenção (aliada ao objetivo de criar um problema), a docente fez uso de uma abordagem interativa/dialógica, a qual, em certos momentos, adquiriu tons de autoridade, configurando novo movimento de reelaboração, em que os alunos foram solicitados a conciliar a regra geral formulada com os resultados "discrepantes". Ela propôs que os alunos explicassem, entre si nos pequenos grupos, como a forma dos objetos interferia na sua flutuação. Vejamos um excerto dessa discussão no Quadro 7.

Quadro 7: Discussão da professora com toda a turma: os casos da tampinha de refrigerante e do papel-alumínio

\begin{tabular}{|l|l|}
\hline \multicolumn{1}{|c|}{ Transcrições } & \multicolumn{1}{|c|}{ Comentários contextuais } \\
\hline $\begin{array}{l}\text { Professora: [...] Vamos lá. Agora ela tá perguntando outra } \\
\text { coisa. É o papel (lrefere-se ao papel-alumínio)]. Vamos } \\
\text { prestar atenção. Atençãão. }\end{array}$ & $\begin{array}{l}\text { A professora chama atenção da } \\
\text { turma para ouvir as ideias de } \\
\text { uma aluna sobre a flutuação do } \\
\text { papel-alumínio. }\end{array}$ \\
\hline $\begin{array}{l}\text { Aluna X: Ele vai tá numa forma de papel, numa forma } \\
\text { extensa. }\end{array}$ & $\begin{array}{l}\text { A aluna justifica a flutuação do } \\
\text { papel-alumínio em água. }\end{array}$ \\
\hline Professora: Extensa. l(pausadamente)] & \\
\hline $\begin{array}{l}\text { Aluna X: E não vai tá aglutinado, por isso ele não vai } \\
\text { afundar. O cilindro de alumínio, ele tá todo aglutinado e vai } \\
\text { afundar. }\end{array}$ & \\
\hline Professora: E se eu fizer uma bolinha de alumínio? & $\begin{array}{l}\text { A professora amassa bastante o } \\
\text { papel- alumínio, faz uma bolinha e } \\
\text { a joga no aquário. A bolinha flutua. }\end{array}$ \\
\hline Alunos: Ohhh. & \\
\hline Várias falas confusas. & Poucos alunos respondem "não". \\
\hline Aluno Y: Aí vai ter oxigênio dentro. & \\
\hline Professora: Por que vai ter o quê? & \\
\hline Alunos: Oxigênio, ar & \\
\hline $\begin{array}{l}\text { Aluno C: Não tem nada a ver com oxigênio não, meu filho. } \\
\text { justificar um pouco, com poucas palavras, como a forma } \\
\text { que a forma influi? }\end{array}$ & \\
\hline Professora: Oxigênio? Vocês concordam com isso? & \\
\hline Alunos: Sim, não. & \\
\hline pó vamos pensar mais um pouquinho. Hoje & \\
\hline
\end{tabular}

Fonte: Elaboração pelos autores deste artigo.

Considerando os movimentos de elaboração e reelaboração, podemos verificar que, enquanto o primeiro alia-se a uma abordagem dialógica, o segundo pode estar associado a uma abordagem dialógica ou de autoridade. Em função desses mo- 
vimentos frente à estrutura da atividade proposta, os alunos passaram a desenvolver as práticas epistêmicas que comentamos. Os percentuais relativos aos movimentos de elaboração e reelaboração predominaram na aula. Foram 44,04\%, 38,84\% e 17,13\% para os movimentos de elaboração, reelaboração e síntese, respectivamente. Em nossa análise, os movimentos epistêmicos foram considerados apenas nos momentos em que a professora deu orientações para o trabalho dos alunos, ou diretamente, nos grupos, ou para toda a turma. Nesse sentido, o tempo referente à discussão final com toda a turma para fechamento de ideias e outros momentos semelhantes não foi considerado para os percentuais dos movimentos epistêmicos.

No Quadro 8, temos os percentuais de tempo obtidos por meio do Vide$\operatorname{ograph}{ }^{\circledR}$ referentes a cada prática epistêmica ao longo das aulas.

Quadro 8: Percentuais de tempo das práticas epistêmicas

\begin{tabular}{|c|c|c|}
\hline Instância social & Práticas epistêmicas & Percentuais de tempo (\%) \\
\hline \multirow{5}{*}{$\begin{array}{l}\text { Produção do } \\
\text { conhecimento }\end{array}$} & Configurando hipóteses & 25,93 \\
\hline & $\begin{array}{l}\text { Considerando conceitos para elaborar } \\
\text { hipóteses }\end{array}$ & 27,13 \\
\hline & Concluindo - checando conclusões & 06,00 \\
\hline & Construindo dados & 04,68 \\
\hline & Ordenando dados & 01,80 \\
\hline \multirow{2}{*}{$\begin{array}{l}\text { Comunicação do } \\
\text { conhecimento }\end{array}$} & $\begin{array}{l}\text { Negociando explicações para os } \\
\text { resultados experimentais obtidos }\end{array}$ & 03,84 \\
\hline & Alcançando generalizações & 14,53 \\
\hline \multirow[t]{2}{*}{$\begin{array}{l}\text { Avaliação do } \\
\text { conhecimento }\end{array}$} & $\begin{array}{l}\text { Avaliando a plausibilidade das hipóteses } \\
\text { - contrastando as ideias próprias e } \\
\text { alheias com as evidências do dia a dia }\end{array}$ & 15,13 \\
\hline & Avaliando a consistência das informações & 00,96 \\
\hline
\end{tabular}

Fonte: SILVA et al., 2012.

É interessante verificar o alto percentual de tempo relacionado à prática "Considerando conceitos para elaborar hipóteses". Conforme comentamos, os alunos passaram a apresentá-la de forma mais evidente após a quarta intervenção da professora, em que ela investiu no movimento de reelaboração, solicitando aos alunos que justificassem no papel as suas ideias.

Outro aspecto que mereceu destaque foi o esforço da professora para que os alunos negociassem os significados entre si, ponderando entre eles as ideias que deveriam ser levadas em conta na discussão. Retomaremos esse aspecto posteriormente.

Situação 2: A atividade investigativa teve por objetivo proporcionar a construção do conceito empírico de reações químicas por meio da análise de cinco fenô- 
menos ${ }^{4}$. As questões propostas no roteiro solicitavam que os alunos descrevessem os fenômenos investigados e, posteriormente, explicassem as suas descrições. Eles também tiveram que responder se os fenômenos envolviam ou não formação de novas substâncias, apresentando argumentos que justificassem as suas asserções. Nesse momento, eles teriam que decidir se cada fenômeno analisado poderia ser considerado ou não uma reação química, aliando os dados a conceitos para justificar a sua conclusão/hipótese. Por fim, eles tiveram que planejar, para cada fenômeno investigado, um roteiro a fim de "constatar" a sua hipótese e executá-lo, se possível.

Discutimos, a seguir, o movimento epistêmico que caracterizou a quarta intervenção da professora no trabalho do grupo de alunos quando estes analisavam a dissolução do permanganato de potássio em água. Essa quarta intervenção constituiu-se de dois episódios: um de discurso de gestão e outro de discurso de conteúdo científico. Este último subdividiu-se em cinco sequências discursivas. Nas duas primeiras sequências, a professora trabalhou com o movimento de elaboração aliado a uma abordagem comunicativa dialógica, em que foi dado espaço para os alunos explicitarem seus pontos de vista sobre o fenômeno. A partir da terceira sequência, a professora passou a assumir o movimento de reelaboração, adotando, a partir daí, sutil e gradativamente, um discurso de autoridade. As transcrições apresentadas a seguir são excertos das sequências inseridas no episódio em que houve a quarta intervenção.

Quadro 9: Elaboração do pensamento inicial sobre o fenômeno - Sequência 1

\begin{tabular}{|c|c|c|c|}
\hline Turno & Locutor & Transcrição da fala & $\begin{array}{l}\text { Movimento } \\
\text { epistêmico }\end{array}$ \\
\hline 18 & Profa. & $\begin{array}{l}\text { Vocês consideram que houve formação de uma nova } \\
\text { substância? }\end{array}$ & \multirow{6}{*}{ Elaboração } \\
\hline 19 & Alunos & Sim. & \\
\hline 21 & Aluno A & Sim, porque a partir da mistura// & \\
\hline 22 & Aluno F & $\begin{array}{l}\text { Deu pra perceber como se uma parte dele tivesse sido } \\
\text { concentrada no fundo. }\end{array}$ & \\
\hline 23 & Profa. & Certo. & \\
\hline 24 & Aluno F & $\begin{array}{l}\text { E com o tempo... olhando bem você dá pra ver meio } \\
\text { que uma linha em cima. Como se uma parte tivesse se } \\
\text { dissolvido com a água e tivesse subido, a substância } \\
\text { mais densa que a água ficou no fundo, mas oh, um } \\
\text { pouco dissolveu com a água. Dá pra ver a mudança na } \\
\text { coloração e que uma parte se dissolveu contrastando. } \\
\text { Outra substância menos densa que a água então ficou } \\
\text { em cima. }\end{array}$ & \\
\hline
\end{tabular}

Fonte: SILVA, 2011.

Nessa sequência, os alunos referiam-se à dissolução do permanganato de potássio como um fenômeno que envolve a formação de uma nova substância. 
Foi perceptível que eles faziam uso desse termo (substância) atribuindo-lhe um significado diferente do científico.

A fim de permitir que os alunos revissem tal concepção e analisassem o fenômeno de uma nova perspectiva, na terceira sequência, a professora chamou a atenção dos estudantes para outra dissolução que lhes era familiar, a dissolução de sal de cozinha em água, direcionando a discussão para as possibilidades de semelhança e diferença entre ambos os fenômenos e para os procedimentos que poderiam ser tomados para que os alunos "constatassem" a hipótese de que, na dissolução do permanganato de potássio em água, havia sido formada nova substância. A partir daí, as discussões tanto dos alunos com a professora quanto entre eles mesmos passaram a considerar a possibilidade de formação de mistura, retomando-se, nessa lógica, as propriedades dos materiais. Nesse momento, o movimento epistêmico que caracterizou o discurso da professora foi o de reelaboração.

Quadro 10: Reelaboração do pensamento inicial - Sequência 3

\begin{tabular}{|c|c|c|c|}
\hline Turno & Locutor & Transcrição da fala & $\begin{array}{l}\text { Movimento } \\
\text { epistêmico }\end{array}$ \\
\hline 1 & Profa. & $\begin{array}{l}\text { Vamos pensar assim [...] quando você coloca o sal de } \\
\text { cozinha em água... }\end{array}$ & \multirow{12}{*}{ Reelaboração } \\
\hline 2 & Aluno $\mathrm{K}$ & Água é água & \\
\hline 3 & Profa. & Você acha que forma uma nova substância também? & \\
\hline 4 & Aluno $\mathrm{F}$ & Não. & \\
\hline 5 & Aluno $\mathrm{K}$ & Só é o mesmo sal. & \\
\hline 6 & Profa.l & $\begin{array}{l}\text { O que leva você a dizer que não, no caso do sal de } \\
\text { cozinha? }\end{array}$ & \\
\hline 7 & Aluno $\mathrm{F}$ & $\begin{array}{l}\text { Não sei, ele simplesmente foi dissolvido na água, } \\
\text { é uma mistura de substâncias, não é, não é uma } \\
\text { substância nova... }\end{array}$ & \\
\hline 8 & Aluno K & Isso que eu tô tentando dizer. & \\
\hline 9 & Aluno $\mathrm{F}$ & Mistura as duas. & \\
\hline 10 & Profa. & $\begin{array}{l}\text { Tá. E como você faria para comprovar, que no caso } \\
\text { do sal de cozinha não houve formação de uma nova } \\
\text { substância? }\end{array}$ & \\
\hline 11 & Aluno $\mathrm{F}$ & Porque você pode separar. & \\
\hline 12 & Aluno $\mathrm{K}$ & Fazendo a destilação. & \\
\hline
\end{tabular}

Fonte: SILVA, 2011.

A discussão na sequência abriu para os alunos a perspectiva de considerar, quanto à dissolução do permanganato de potássio em água, os mesmos procedimentos que utilizariam para constatar que, na dissolução do sal de cozinha em água, não há formação de nova substância. Além disso, os alunos passaram a trazer para a discussão conhecimentos já abordados em aulas regulares anteriores, como os tipos de mistura e as formas de fracionamento. Nessa perspectiva, a professora 
contribuiu substancialmente para os alunos articularem de forma mais producente os saberes já introduzidos em aulas anteriores, os quais passaram a ser utilizados para dar sentido ao fenômeno e, ainda, para planejar e performar as ações planejadas.

$\mathrm{Na}$ sequência seguinte, a professora continuou a investir no movimento de reelaboração, intercalando-o, então, com os movimentos de síntese, informação e correção. A discussão desenvolvida indicou que os alunos passaram a considerar a possibilidade de que não teria havido a formação de nova substância no fenômeno, tratando-se apenas de uma "mistura" de substâncias.

$\mathrm{Na}$ sequência 5, a professora finalizou o movimento de reelaboração, e, como consequência, apareceu, de forma mais pronunciada, o movimento de instrução. Entretanto, tal movimento surgiu inter-relacionado com os anteriores, ou seja, a professora não instruiu os alunos sem antes ter feito o esforço de compreender as suas ideias e de permitir que eles refletissem sobre elas.

Quadro 11: Reelaboração do pensamento inicial: fase final - Sequência 5

\begin{tabular}{|c|c|c|c|}
\hline Turno & Locutor & Transcrição da fala & $\begin{array}{l}\text { Movimento } \\
\text { epistêmico }\end{array}$ \\
\hline 6 & Profa & $\begin{array}{l}\text { Vocês têm que dizer, justificar, e aqui, ó, na quinta } \\
\text { questão vocês vão dizer... não precisa escrever demais } \\
\text { não, vocês colocam o que vocês fariam pra poder, é... } \\
\text { pra poder... }\end{array}$ & Reelaboração \\
\hline 7 & Aluno V & Separar... & \\
\hline 8 & Aluno F & Ver & \\
\hline 9 & Profa & $\begin{array}{l}\text { Ver não, pra poder se certificar melhor se é a mesma } \\
\text { substância ou não. }\end{array}$ & Correção \\
\hline 10 & Aluno A & É aquilo que eu disse. & \\
\hline 11 & Profa. & $\begin{array}{l}\text { Óh, psiu! Vocês viram as características iniciais do } \\
\text { sistema, não viram? }\end{array}$ & Reelaboração \\
\hline 12 & Aluno F & hum hum & \\
\hline 13 & Profa & $\begin{array}{l}\text { Ou seja, vocês viram a água e o permanganato, } \\
\text { separadamente não é? Aí vocês misturaram os dois. } \\
\text { Prá saber se houve formação de uma nova substância } \\
\text { você vai fazer o quê? Vocês falaram ainda há pouco. }\end{array}$ & Reelaboração \\
\hline 14 & Aluno F & Tentar separar. & \\
\hline 15 & Profa & $\begin{array}{l}\text { Tentar separar e aí, você vai, você vai fazer alguma } \\
\text { comparação não é? Entre o que vocês têm agora com o } \\
\text { que tinham inicialmente, não é verdade? }\end{array}$ & Instrução \\
\hline 16 & Aluno $\mathrm{F}$ & Isso. & \\
\hline
\end{tabular}

Fonte: SILVA, 2011.

Os percentuais relativos aos movimentos de elaboração e reelaboração foram os maiores entre os demais $(33,79 \%$ e $33,11 \%$, respectivamente). Todavia, os outros movimentos, com menores percentuais, foram também relevantes, no 
sentido de proporcionarem o avanço das ideias dos alunos e a configuração de determinadas práticas epistêmicas. Por meio dos movimentos de instrução, confirmação, correção e síntese $(17,41 \%, 2,96 \%, 7,39 \%$ e 5,35\%, respectivamente), a professora atuou de forma mais incisiva, disponibilizando informações, dando respostas diretas para questionamentos dos alunos ou, ainda, permitindo ou negando determinadas ações por eles planejadas.

Vamos, neste momento, apresentar algumas das práticas epistêmicas desenvolvidas pelos alunos as quais podem ser relacionadas à discussão estabelecida entre o grupo e a professora. Consideramos, nesta análise, os dois episódios posteriores àquele que discutimos acima, em que a professora interagiu com o grupo de alunos.

Quadro 12: Práticas epistêmicas de produção do conhecimento

\begin{tabular}{|c|c|}
\hline Transcrições & $\begin{array}{c}\text { Práticas } \\
\text { epistêmicas }\end{array}$ \\
\hline $\begin{array}{l}\text { Aluno V: Não, não é assim não. É assim... isso pra dizer que é uma } \\
\text { substância nova, você vai pegar as características. Qual a cor dessa } \\
\text { substância? } \\
\text { Aluno K: Tem cheiro, ou não? } \\
\text { Aluno F: Não. } \\
\text { Aluno A: Ah, roxa, roxa. } \\
\text { Aluno K: Tem certeza? } \\
\text { Aluno F: Continua inodora. } \\
\text { Aluno V: Qual o cheiro? } \\
\text { Aluno K: Tem cheiro não, cara. } \\
\text { Aluno F: Não tem. Fraquíssimo, não dá pra identificar. } \\
\text { Aluno K: É leve? Vai, sente aí. } \\
\text { Aluno A: Deixe eu ver. } \\
\text { Aluno F: É quase inodora. }\end{array}$ & $\begin{array}{l}\text { Dando sentido } \\
\text { aos padrões de } \\
\text { dados } \\
\text { - Construindo } \\
\text { dados. }\end{array}$ \\
\hline $\begin{array}{l}\text { Aluno V: eu acho que se houve muitas transformações, muitas diferenças } \\
\text { nas características é uma nova substância, mas se houve meio que uma } \\
\text { junção das características dos dois é apenas uma mistura. } \\
\text { Aluno F: Então, é uma mistura. } \\
\text { Aluno A: Uma mistura. }\end{array}$ & $\begin{array}{l}\text { Articulando os } \\
\text { saberes - Usando } \\
\text { dados e conceitos } \\
\text { para elaborar } \\
\text { hipóteses. }\end{array}$ \\
\hline $\begin{array}{l}\text { Aluno F: “Elabore um esquema, em que esses procedimentos apareçam } \\
\text { ordenados. Você pode buscar os procedimentos considerados”. ((A aluna } \\
\text { lê a questão proposta no roteiro)]. Certo, então seria destilação. } \\
\text { Aluno K: Eu preferiria usar a destilação, mas tem inúmeros processos. [...] } \\
\text { Aluno K: A gente podia evaporar, seria bem interessante a gente fazer isso. } \\
\text { Aluno A: Fazer o quê? } \\
\text { Aluno F: Como? } \\
\text { Aluno K: Porque... Que nem eu faço com sal. O sal quando eu coloco ele } \\
\text { na panela eu misturo ele com a água... } \\
\text { ((Conversas paralelas)) } \\
\text { Aluno K: É... sim, mas é preciso evaporar. Porque tipo, quando eu misturo o } \\
\text { sal com a água, quando tento evaporar o sal mesmo quando está misturado } \\
\text { com a água, ele acaba ficando na parte debaixo, porque ele sempre é mais } \\
\text { denso e mesmo ele estando misturado com a água que o // } \\
\text { Aluno F: Tá ok. }\end{array}$ & $\begin{array}{l} \\
\text { Articulando } \\
\text { os saberes - } \\
\text { Usando conceitos } \\
\text { para planejar } \\
\text { e desenvolver } \\
\text { ações. }\end{array}$ \\
\hline
\end{tabular}


No quadro 13, temos os percentuais de tempo obtidos pelo Videograph referentes a cada prática epistêmica ao longo das aulas.

Quadro 13: Percentuais de tempo de cada prática assumida por instância social do conhecimento

\begin{tabular}{|c|c|c|}
\hline Instância & Práticas Epistémicas & Percentuais \\
\hline \multirow{6}{*}{ Produção } & Monitorando o progresso & $5,67 \%$ \\
\hline & Executando estratégias orientadas por planos ou objetivos & $7,15 \%$ \\
\hline & Utilizando conceitos para planejar e realizar ações & $5,88 \%$ \\
\hline & Articulando conhecimento observacional e conceitual & $19,53 \%$ \\
\hline & Construindo significados & $2,29 \%$ \\
\hline & Construindo dados & $12,93 \%$ \\
\hline \multirow{2}{*}{ Comunicação } & Relacionando diferentes linguagens & $1,65 \%$ \\
\hline & Negociando explicações & $19,01 \%$ \\
\hline \multirow{3}{*}{ Avaliação } & Usando dados para avaliação de conclusões/hipóteses & $8,25 \%$ \\
\hline & Usando conceitos para avaliação de conclusões/hipóteses & $2,88 \%$ \\
\hline & Justificando as próprias conclusões & $14,77 \%$ \\
\hline
\end{tabular}

Considerando ambas as situações que apresentamos, as práticas epistêmicas verificadas em cada uma delas são, de um modo geral, diferentes entre si, e isso pode ser entendido tendo-se em vista as diferenças entre as atividades desenvolvidas, seus objetivos e as questões propostas no roteiro, entre outros aspectos. Nesse sentido, é certo afirmar que, embora algumas práticas epistêmicas possam ser recorrentes em diferentes atividades de natureza investigativa, elas se encontram intimamente relacionadas à estrutura da atividade, variando em função desta, além de outros fatores como a natureza do conhecimento trabalhado e a condução do professor.

Um aspecto relevante a diferenciar a situação 1 da 2 foi o fato de que a primeira envolveu a percepção de um fenômeno (a flutuação ou não de objetos em água) sobre o qual não houve controvérsia empírica, ou seja, após os testes, não restou dúvida quanto à capacidade de flutuação de distintos objetos, feitos de materiais diferentes ou de um mesmo material. A partir daí, os alunos tiveram que contrastar suas previsões com os resultados experimentais e elaborar explicações para os dados obtidos, incluindo os considerados discrepantes. Na situação 2, para cada fenômeno verificado, os alunos elaboraram as suas explicações tendo também em vista dados empíricos "incontroversos", porém tiveram que concluir se as características de cada fenômeno seriam indicativas ou não de formação de novas substâncias. Isso fez com que retomassem definições, planejassem e executassem novos procedimentos experimentais, obtendo novos dados que respaldassem as suas 
conclusões ou as refutassem. O maior número de informações envolvidas nos dados e as diferentes possibilidades de articulá-los em variadas interpretações na Situação 2 podem ser percebidos como as principais diferenças entre esta e a Situação 1.

Apesar das diferenças, é interessante constatar que houve uma maior aparição das práticas relacionadas à instância de produção do conhecimento ante as demais em ambas as situações. Na primeira situação, elas representaram 65,54\%, e, na segunda, 53,45\% do tempo codificado em relação ao total de práticas verificadas. Na situação 1, o alto percentual da instância de produção do conhecimento relacionou-se ao tempo considerável destinado à formulação e aos testes de hipóteses para a flutuação dos objetos indicados no roteiro. Na situação 2, a porcentagem se justificou considerando-se que os alunos, a cada experimento desenvolvido, retornavam várias vezes à instância de produção, buscando ou gerando novas evidências experimentais a fim de elaborarem e/ou avaliarem as suas hipóteses e, desse modo, justificarem as suas conclusões.

De certo modo, é esperado que a instância de produção do conhecimento apresente sempre percentuais de tempo expressivos em diferentes atividades investigativas, pois os processos de planejamento, obtenção e ordenação de dados e elaboração de hipóteses, ainda que envolvendo experimentos simples, demandam tempo. Quanto a isso, em determinados momentos da Situação 2, observamos que as instâncias de produção e avaliação do conhecimento se sobrepuseram. Ao tempo em que os alunos elaboravam as suas conclusões tendo em vista os resultados experimentais, buscavam também obter novos dados ou retomar os antigos para avaliarem as conclusões/hipóteses formuladas. De forma mais específica, consideramos que eles fizeram uso de dados para avaliar as suas hipóteses, contrastando conclusões e evidências na análise de cada experimento.

Se entendermos que essa relação entre dados e conclusões, tendo em vista conhecimentos que os interligam, é constitutiva da elaboração de argumentos que permeiam as atividades investigativas em salas de aula de ciências, é compreensível que a instância de avaliação na Situação 2 tenha apresentado percentual de tempo razoavelmente mais alto que o da Situação 1 (16,09\% para a Situação 1 e 25,90\% para a Situação 2). É relevante observar também que, na Situação 1, tal instância obteve o percentual mais baixo entre os demais, sendo seguido pelo percentual relativo à instância de comunicação do conhecimento (18,37\%). Isso nos leva a considerar que, em tal situação, os alunos passaram "pouco" tempo, em relação ao destinado às práticas de outras instâncias, elaborando uma análise mais criteriosa das conclusões alcançadas, sobretudo após a obtenção dos dados experimentais. Nesse sentido, a elaboração de argumentos, entendida como o ato de justificar a adoção de uma determinada conclusão explicativa, algumas vezes em detrimento de outras, usando dados experimentais seguros e conhecimentos que ligam tais dados às conclusões (OSBORNE; PATTERSON, 2011), foi menos desenvolvida que outras práticas durante a atividade investigativa da Situação 1, bem como quando comparada à Situação 2. Na primeira, a discrepância entre os percentuais de produção e os demais foi maior que na segunda. 
Tomando como base o modelo de argumentação de Toulmin (2006), Osborne e Patterson (2011) diferenciam o argumento da explicação. Para os autores, a explicação aprofunda o conhecimento sobre um fenômeno, geralmente por meio de relações causais entre fatos científicos. A explicação é a resposta a um questionamento, um porquê sobre um explanandum (fenômeno ou característica cuja existência é indubitável). A argumentação, por sua vez, caracteriza-se pelo ato de justificar a adoção de uma explicação, muitas vezes em detrimento de outras, oferecendo as evidências necessárias para estabelecer a validade de uma asserção. $\mathrm{O}$ foco de qualquer argumento em torno de uma explicação é verificar se tal explicação é satisfatória ou se é melhor que outras. Trata-se de justificar a validade de uma asserção (claim) ou de persuadir uma audiência. Nessa perspectiva, os autores observam que os argumentos envolvem dados, conclusões e garantias de inferência, tendo em vista o modelo de Toulmin (2006).

Osborne e Patterson (2011) observam ainda que confusões entre os dois termos surgem porque argumentos são essenciais no processo de julgar a validade de alguma explicação quando existem várias para um mesmo fenômeno. Nesse sentido, as duas práticas epistêmicas podem surgir associadas. Na ciência real, isso acontece, pois os cientistas estão engajados em elaborar e validar explicações. $\mathrm{Na}$ ciência escolar, o ensino por investigação se aproxima desse processo, pois os alunos retomam conhecimentos prévios para elaborar hipóteses explicativas e, indo além, buscam avaliar sua validade estabelecendo relações entre os dados e as asserções de conhecimento. Nesse sentido, por meio de atividades investigativas, eles vão apreendendo aspectos inerentes à natureza do conhecimento científico.

Em ambos os casos aqui apresentados, os alunos negociaram explicações, colaborativamente, buscando conceitos para elaborar suas hipóteses e/ou planejando novos procedimentos experimentais. O movimento argumentativo surgiu quando os alunos buscaram avaliar as suas hipóteses explicativas ou novas conclusões, relacionando-as aos dados analisados.

Nessa perspectiva, entendemos que o desenvolvimento das práticas epistêmicas informadas em cada sequência aqui discutida certamente contribuiu para a percepção dos alunos acerca da natureza do conhecimento científico, sobretudo quanto à relação entre evidências experimentais e teorias, o que é constitutivo de tal conhecimento. Tendo em vista, portanto, a elaboração de sequências didáticas envolvendo atividades investigativas, entendemos como relevante atentar para estruturas que gerem espaço para todas as instâncias sociais que envolvem diferentes práticas epistêmicas, entendendo-as como necessárias à construção de argumentos resultantes de um explícito processo de articulação entre dados experimentais e conclusões, permeado pelos conceitos científicos que sustentam tal relação.

O desenvolvimento de uma discussão acerca de diferentes possibilidades explicativas, tendo em vista a relação dialética entre empiria e teoria, contribuirá ainda mais para a percepção dos alunos acerca da natureza da ciência e dos conhecimentos científicos. Nesse sentido, a articulação entre diferentes práticas epistêmicas é percebida como constitutiva da construção de uma forma de olhar, dar 
sentido aos fenômenos e legitimar os conhecimentos produzidos na perspectiva da ciência escolar. A argumentação em prol dessa legitimação, que é em si uma prática epistêmica, alimenta-se das várias práticas epistêmicas que se instauram nas três instâncias sociais indicadas por Kelly (2005) - produção, comunicação, avaliação do conhecimento.

Na perspectiva do desenvolvimento das práticas epistêmicas, voltamo-nos para os movimentos epistêmicos de elaboração e reelaboração articulados pela professora. Por meio deste último tipo, sobretudo, os alunos foram instigados a retomar conceitos já trabalhados e articulá-los na elaboração de previsões para os resultados experimentais, elaborando asserções fundamentadas ao longo do processo.

Durante cada aula, a professora interagiu com o grupo de alunos pesquisado em um número considerável de vezes. Analisando essas intervenções, pudemos verificar certo ritmo com o qual ela orientou o trabalho dos alunos. Inicialmente, desenvolveu o movimento de elaboração. Conforme definimos, o discurso da professora categorizado como tal envolveu questionamentos iniciais que permitiram aos alunos, em interação com os fenômenos, elaborar e explicitar suas percepções sobre estes. Em relação a isso, consideramos que as ideias apresentadas pelos alunos no início do processo de ensino - suas ideias prévias - guardam em si a dimensão da construção que se dá na interação com o professor, envolvendo o tipo de pergunta que é proposta, a sua forma, o fenômeno analisado, enfim, o contexto geral que envolve a emergência das suas concepções. Desse modo, as ações da professora que fizeram as concepções iniciais dos alunos emergirem corresponderam a um movimento epistêmico de elaboração, pois as concepções apresentadas foram formatadas em função da sua intervenção.

Em seguida, a professora desenvolveu um movimento de reelaboração, chamando a atenção dos alunos para aspectos desconsiderados, promovendo uma problematização do pensamento inicial e uma consequente reformulação deste pensamento. Tal movimento se deu, inicialmente, de forma sutil. Em nossa análise, percebemos que os alunos não identificaram de pronto que a professora insistia, muitas vezes, em uma mudança considerável no seu pensamento inicial. Assim, as práticas epistêmicas performadas pelos alunos puderam ser percebidas em íntima relação com os movimentos articulados pela professora, os quais se associavam à estrutura de cada atividade. Estas foram desenvolvidas tendo-se em vista um roteiro que, por meio de questionamentos e procedimentos propostos, dava certa direção à investigação, deixando, todavia, bastante espaço para as iniciativas dos alunos.

Ao longo das atividades, novos significados foram construídos, enquanto outros foram retomados e ressignificados. O papel da professora para que esses processos acontecessem foi fundamental. Os alunos partiram de descrições e explicações permeadas por concepções distantes das científicas e que expressavam pouca tentativa de articulação entre os conceitos já introduzidos para interpretação dos fenômenos. Por meio da atuação da professora chamando atenção para fenômenos familiares, semelhantes àqueles já analisados, ou insistindo para que 
considerassem conceitos anteriormente trabalhados, os alunos passaram a elaborar novas possibilidades em sua interpretação.

Outro aspecto a ser ressaltado foi o esforço da professora em insistir para que os alunos interagissem e discutissem entre si, negociando significados e, portanto, estabelecendo critérios para eleger conhecimentos e práticas que deveriam ser levados em conta ao longo do processo. Nesse sentido, é possível entender que se fortalece nos grupos de alunos a incorporação de aspectos relevantes que se encontram na base das investigações científicas reais.

\section{CONSIDERACְ̃̃ES FINAIS}

Apresentamos neste artigo a análise de duas situações de ensino considerando as práticas epistêmicas desenvolvidas pelos alunos. Buscamos caracterizar as práticas relacionando-as aos movimentos epistêmicos articulados pela professora. Foi perceptível que as intervenções da professora no grupo de alunos analisado foram fundamentais para a emergência das práticas verificadas. Ao tempo em que os movimentos epistêmicos da professora favoreceram a incorporação de aspectos fundamentais das investigações científicas pelos alunos, favoreceram também o processo de evolução conceitual. Nesse sentido, conceitos anteriores foram retomados, e outros novos, elaborados.

Um aspecto importante da pesquisa, o qual focalizamos neste artigo, é a concepção de Natureza da Ciência, que cabe ao seu ensino desenvolver nos alunos. Conforme comentamos, é consenso na comunidade científica que o ensino de ciências não deve se preocupar apenas em proporcionar a aquisição de conceitos e habilidades experimentais pelos alunos, mas lhes possibilitar também uma compreensão acerca da Natureza da Ciência e dos saberes científicos.

Embora uma adequada concepção da Natureza da Ciência não seja elaborada apenas por meio do desenvolvimento de atividades investigativas, tal dimensão é fundamental na sua construção. Nesse sentido, é incentivado o desenvolvimento desse tipo de atividade, em que os alunos elaboram questões, planejam e desenvolvem experimentos para testar suas hipóteses e chegam a construir novos conceitos em meio a interações e debates entre colegas. Desse modo, afirma-se que o conceito de práticas epistêmicas articulado às pesquisas voltadas para as interações dos alunos ao longo dos processos de produção e legitimação dos saberes favorece a percepção do movimento discursivo dos alunos na apropriação de aspectos constitutivos da análise dos fenômenos na perspectiva da ciência escolar.

\section{NOTAS}

${ }^{1}$ Atividade adaptada do livro: MORTIMER; MACHADO. Química. Vol. 1. São Paulo: Ed. Scipione, 2012. 
${ }^{2}$ GPEA: Grupo de Pesquisa em Práticas Educativas e Aprendizagem na Educação Básica. UFS/ CNPQ.

${ }^{3}$ Os alunos verificaram e analisaram o comportamento dos seguintes objetos em água: blocos de madeira (pequeno e grande), bloco de isopor, alfinete, clipe, cilindro de alumínio, tampa de refrigerante (de metal) e papel-alumínio.

${ }^{4} \mathrm{O}$ roteiro proposto estava segmentado em cinco atividades investigativas envolvendo os seguintes experimentos: a dissolução do permanganato de potássio $\left(\mathrm{KMnO}_{4}\right)$ em água; a interação do zinco ( $\mathrm{Zn})$ com o ácido clorídrico $(\mathrm{HCl})$; a interação entre o açúcar e o ácido sulfúrico $\left(\mathrm{H}_{2} \mathrm{SO}_{4}\right)$; a interação entre as soluções de sulfato de cobre $\mathrm{II}\left(\mathrm{CuSO}_{4}\right)$ e de hidróxido de sódio $(\mathrm{NaOH})$; e a sublimação do iodo $\left(I_{2}\right)$.

\section{REFERÊNCIAS}

ARAÚJO, A. O. O uso do tempo e das práticas epistêmicas em aulas práticas de química. 2008. 143f. Dissertação (Mestrado em Educação) - Faculdade de Educação, UFMG, Belo Horizonte, Minas Gerais.

FREIRE, F. A.; SILVA, A. C. T. ; BORGES, D. R. ; NASCIMENTO, E. D. O. Atividades Investigativas: um olhar sobre as práticas epistêmicas. In: GALIETA, T; GIRALDI, P. M. (Org.). Linguagens e Discursos na Educação em Ciências. 1ed. Rio de Janeiro: Editora Multifoco, 2014, p. 408421.

JIMÈNEZ-ALEIXANDRE M. P.; reigosa, C. Contextualizing practices across epistemic levels in the Chemistry laboratory. Science Education, n. 90, p. 707-733, 2006.

; MORTIMER, E. F.; SILVA, A. C. T; BUSTAMANTE, J. D. Epistemic practices: an analytical framework for science classrooms. In: ANNUAL MEETING OF AMERICAN EDUCATIONAL RESEARCH ASSOCIATION (AERA). New York, 2008. Proceedings of AERA 2008. New York: AERA, 2008.

KELLY, G. J. Inquiry, activity, and epistemic practices. In: INQUIRY CONFERENCE ON DEVELOPING A CONSENSUS RESEARCH AGENDA, 2005, New Brunswick. Proceeding of Inquiry Conference on Developing a Consensus Research Agenda. New Brunswick: 2005

; DUSCHL, R. A. Toward a research agenda for epistemological studies in science education. In: ANNUAL MEETING OF NATIONAL ASSOCIATION OF RESEARCH IN SCIENCE TEACHING (NARST), 75., 2002, New Orleans. Proceeding of the NARST Annual Meeting. Reston: NARST, 2002.

; TAKAO, A. Epistemic levels in argument: an analysis of university oceanography students'use of evidence in writing. Science Education, n 86, p. 314-342, 2002.

LEMKE, J. L. Articulating communities: sociocultural perspectives on science education. Journal of research in science teaching, v. 38, n. 3, p. 296-316, 2001.

LIDAR, M; LUNDQVIST, E.; OSTMAN, L. Teaching and learning in the science classroom: the interplay between teachers' epistemological moves and students' practical epistemology. Science Education, n. 90, p. 148-163, 2005.

MORTIMER. E. F; MASSICAME, T; BUTTY, C; TIBERGHIEN, E. Uma metodologia para caracterizar os gêneros de discurso como tipos de estratégias enunciativas nas aulas de ciências. In: NARDI, R. A pesquisa em ensino de ciência no Brasil: alguns recortes. São Paulo: Escrituras, 2007.

MORTIMER, E. F.SCOTT, P. Meaning making in secondary science classrooms. Buckingham: Open University Press, 2003.

OSBORNE, J; PATTERSON, A. Scientific argument and explanation: A necessary distinction? Science Education, v. 95, p. 627-638, 2011. 
SANDOVAL, W. A. Students' uses of data as evidence in scientific explanations. In: ANNUAL MEETING OF AMERICAN EDUCATIONAL RESEARCH ASSOCIATION (AERA). 74., Seattle, 2001. Proceeding of the NARST Annual Meeting. Seattle: NARST, 2001.

. Understandings students' pratical epistemologies and their influence on learning through inquiry. Science Education, v. 89, p. 634-656, 2005.

; REISER, B. J. Explanation-driven inquiry: integrating conceptual and epistemic scaffolds for scientific inquiry. Science Education, n. 88, p. 345-372, 2004.

; MORRISON, K. High school' ideas about theories and theories change after a biological inquiry unit. Journal of research in science teaching, v. 40, n. 4, p. 369-393, 2003.

SILVA, A. C. T. Práticas e movimentos epistêmicos em atividades investigativas de Química. In: ENCONTRO NACIONAL DE PESQUISA EM EDUCAÇÃO EM CIÊNCIAS (ENPEC), 8., Campinas, 2011. Anais... ABRAPEC: Rio de Janeiro, 2011.

; NASCIMENTO, E.D.O.; FRANÇA, E.C.M.; FREIRE, F.A.; NUNES, J.M. Densidade e flutuação dos objetos: práticas e movimentos epistêmicos em uma sala de aula de ciências. In: Encontro Nacional de Ensino de Química (ENEQ), 16., Salvador. Anais do XVI Encontro Nacional de Ensino de Química (ENEQ). Salvador: ENEQ, 2012.

TOULMIN, S.E. Os usos do argumento. São Paulo: Contraponto, 2006.

TAKAO, A. Y.; KELLY, G. J. Assessment of evidence in university students' scientific writing. Science \& Education, n. 12, p. 341-363, 2003. 